\title{
Državna jamstva i financijske obveze javnih trgovačkih društava iz cestovnog prometa
}

\author{
ANTO BAJO, Institut za javne financije \\ JELENA PETRUŠIĆ, Ekonomski fakultet Zagreb
}

Glavni je cilj rada pružiti pregled visine i strukture financijskih obveza i državnih jamstava odobrenih od $200 I$. do 20I4. javnim poduzećima iz cestovnog prometa - Hrvatskim autocestama d.o.o. (HAC), Hrvatskim cestama d.o.o. (HC) i Autocesti Rijeka-Zagreb d.d. (ARZ) Država je do 20I4. gotovo u cijelosti jamčila financijske obveze tih poduzeća - iznos državnih jamstava približno odgovara visini nastalih obveza. HC je od 20II. uključen u statistiku duga opće države, usklađene po metodologiji Eurostata, a od 20I4. retroaktivno su uključene i obveze HAC-a i ARZ-a. Uvrštavanje državnih jamstava cestovnih poduzeća u izravni dug opće države utjecalo je na njegov rast. Analiza jamstava korisna je zbog dobivanja cjelovitijih informacija o visini duga, uvjetima zaduživanja te dospijećima obveza poduzeća iz cestovnog prometa.

\section{JAVNA PODUZEĆA IZ GESTOVNOG PROMETA}

Hrvatske ceste d.o.o. je javno poduzeće za upravljanje, građenje, rekonstrukciju i održavanje državnih cesta. ${ }^{\mathrm{I}}$ Društvo je osnovano i upisano u Sudski registar 200I., temeljem Vladine Odluke o podjeli i preoblikovanju Hrvatske uprave za ceste, čime nastaju Hrvatske autoceste i Hrvatske ceste, a jedini osnivač je RH.

Hrvatske autoceste d.o.o. je javno poduzeće osnovano za projektiranje, redovito i izvanredno održavanje autocesta i cestovnih objekata, naplatu cestarine, financiranje građenja i održavanja te ostale djelatnosti gospodarenja i upravljanja autocestama. HAC i HC financijske izvještaje sastavljaju prema međunarodnim računovodstvenim standardima i prema Zakonu o cestama. Prema Zakonu o cestama, HC i HAC su obvezni primjenjivati kapitalni pristup (jer u bilanci imaju javno dobro), prema kojem se rezultat poslovanja ne prikazuje ni kao dobit ni kao gubitak ${ }^{2}$ Nastala razlika vlastitih prihoda i rashoda ostvarenih u tekućoj poslovnoj godini nadoknađuje se na teret javnog kapitala.

\footnotetext{
I Zakon o cestama. Dostupno na: http://www.zakon.hr/z/244/Zakon-o-javnim-cestama

${ }^{2}$ Društva koja u bilanci imaju javno dobro, primjenjuju kapitalni pristup pri evidenciji pojedinih poslovnih događaja. Kapitalni pristup podrazumijeva dvije usporedne evidencije javnog dobra i vlastitih prihoda i rashoda, te imovine, obveza i kapitala. Prema tom pristupu, ukoliko vlastiti prihodi nisu dostatni za pokriće ukupnih rashoda, razlika se pokriva iz javnog kapitala kao i dio troška amortizacije koji se ne može pokriti vlastitim prihodima, te financijski rashodi. Višak prihoda nad rashodima poslovanja povećava
} 
Autocesta Rijeka-Zagreb d.d. osnovano je 1997. i u cijelosti je u vlasništvu RH. Gospodarska svrha je financiranje, građenje, gospodarenje i održavanje autoceste Rijeka-Zagreb, te njezinih cestovnih i pratećih objekata na cestovnom zemljištu u sklopu ostvarivanja prava iz Koncesijskog ugovora. Koncesija je dana Društvu na 32 godine i II mjeseci.

Restrukturiranje i monetizacija duga HAC-a i ARZ-a. U 2OI3. obavljeno je djelomično restrukturiranje HACa i ARZ-a, temeljeno na Programu restrukturiranja za razdoblje 20I2. do 2015., kojeg je izradio HAC i Ministarstvo mora, prometa i infrastrukture (HAC (2O12). Cilj je bio usklađivanje poslovanja društava s europskim standardima (promjena organizacijske strukture, učinkovitije financijsko upravljanje, smanjenje broja zaposlenih, uvođenje korporativne strategije poslovanja) i priprema za monetizaciju njihova dijela javnog duga dodjelom koncesija za upravljanje i održavanje autocesta. U travnju 2013. počelo je s radom društvo Hrvatske autoceste održavanje i naplata cestarine d.o.o. (HAC-ONC d.o.o.) kao društvo kći HAC-a, a pripojeno mu je i novoosnovano društvo Autocesta Rijeka-Zagreb za održavanje i naplatu d.o.o. (ARZ-ON) kao društvo kći ARZ-a d.d. U isto vrijeme, ARZ i HAC su ostali u vlasništvu RH, a spajanje društva ARZ-ON d.o.o. društvu HAC-ONC d.o.o. obavljeno je upisom u sudski registar Trgovačkog suda u Zagrebu 3I. siječnja 2014.

\section{DRŽAVNA JAMSTVA PODUZEĆIMA IZ GESTOVNOG PROMETA}

Vlada donosi odluku o davanju svih državnih jamstava, osim jamstava za koje je mjerodavan Sabor, i to na prijedlog Ministarstva financija. Sabor donosi posebne odluke koje se odnose na državna jamstva izdana u korist međunarodnih financijskih institucija, kao što su Međunarodna banka za obnovu i razvoj(IBRD), Europska banka za obnovu i razvoj (EBRD) i Europska investicijska banka (EIB), te za HC d.o.o. i HAC d.o.o. Ta jamstva ne ulaze u godišnje ograničenje izdavanja državnih jamstava propisano zakonom o izvršavanju državnog proračuna za pojedinu godinu.

Poduzećima iz cestovnog prometa od 200I. do 20I3. odobreno je 80 jamstava u iznosu od 56,7 mlrd. kuna. Najviše je jamstava (9) izdano 2009. (u ukupnom iznosu od 5,2 mlrd. kuna), a najveći iznos (od 8 mlrd. kuna) jamstava odobren je u 20II. Od 200I. do 20I3. udio jamstava za tri društva u ukupnim jamstvima odobrenih sektoru prometa veći je od 55\%. U 2004. i 2008. gotovo sva odobrena jamstva sektoru prometa odnosila su se na cestovni, a samo u posljednje tri godine više od $60 \%$ jamstava odobreno je poduzećima iz cestovnog prometa.

Godišnje se prosječno sektoru prometa odobri oko 1,2\% BDP-a državnih jamstava, od čega najveći dio poduzećima iz cestovnog prometa. Dio jamstava je istekao, odnosno dio kreditnih obveza poduzeća su otplatila.

Najveći iznos jamstava odobren je HAC-u, čak 35,3 mlrd. kuna, a slijedi HC s II,4 mlrd. te ARZ s IO,I mlrd. kuna (tabl. 2).

javni kapital, dok se manjak prihoda do visine stvarno nastalih rashoda poslovanja nadoknađuje na teret javnog kapitala (smanjuje se javni kapital).

2 NEWSLETTER 92 | A. BAJO i J. PETRUŠIĆl Državna jamstva i financijske obveze javnih trgovačkih... | Institut za javne financije 


\section{Tablica I.}

Pregled odobrenih državnih jamstava u sektoru prometa (u mlrd. kuna), te udio cestovnog prometa u ukupnim i jamstvima sektoru prometa (u \%) od 200I. do 2014.

\begin{tabular}{|c|c|c|c|c|c|c|c|}
\hline $\begin{array}{c}\text { Ukupno } \\
\text { odobrena } \\
\text { jamstva } \\
\text { u mlrd. }\end{array}$ & $\begin{array}{c}\text { Odobrena } \\
\text { jamstva } \\
\text { sektoru } \\
\text { prometa } \\
\text { u mlrd. }\end{array}$ & $\begin{array}{c}\text { Odobrena } \\
\text { jamstva } \\
\text { sektoru } \\
\text { cestovnog } \\
\text { prometa } \\
\text { u mlrd. (HC, } \\
\text { HAC, ARZ) }\end{array}$ & $\begin{array}{c}\text { Jamstava } \\
\text { cestovnom } \\
\text { prometu u } \\
\% \text { ukupnih } \\
\text { jamstava }\end{array}$ & $\begin{array}{c}\text { Jamstva } \\
\text { cestovnom } \\
\text { prometu } \\
\text { u \% } \\
\text { jamstava } \\
\text { sektoru } \\
\text { prometa }\end{array}$ & $\begin{array}{c}\text { Ukupno } \\
\text { odobrena } \\
\text { jamstva } \\
\text { u \% BDP-a }\end{array}$ & $\begin{array}{c}\text { Jamstva } \\
\text { odobrena } \\
\text { prometu } \\
\text { u \% BDP-a }\end{array}$ & $\begin{array}{c}\text { Jamstva } \\
\text { odobrena } \\
\text { cestovnom } \\
\text { prometu } \\
\text { u \% BDP-a }\end{array}$ \\
\hline
\end{tabular}

\begin{tabular}{|c|c|c|c|c|c|c|c|c|}
\hline 2001. & 7,7 & 4,5 & 3,4 & 43 & 74 & 4,0 & 2,3 & $\mathrm{I}, 7$ \\
\hline 2002 & 8,4 & 5,6 & 3,9 & 47 & 70 & 4,0 & 2,6 & I,9 \\
\hline 2003. & 9,0 & 6,0 & 3,3 & 37 & 55 & 3,9 & 2,6 & $\mathrm{I}, 4$ \\
\hline 2004 & 5,8 & 2,4 & 2,4 & $4 \mathrm{I}$ & 99 & 2,3 & 0,9 & 0,9 \\
\hline 2005 & 3,7 & 2,7 & 2,5 & 68 & 93 & $\mathrm{I}, 4$ & $\mathrm{I}, \mathrm{O}$ & 0,9 \\
\hline 2006. & 9,4 & 6,2 & 4,6 & 49 & 73 & 3,2 & $2, \mathrm{I}$ & I,6 \\
\hline 2007. & I4. 8 & 8,3 & 6,5 & 44 & 76 & 4,6 & 2,6 & 2,0 \\
\hline 2008 & 7,9 & 5,4 & 5,3 & 67 & 98 & 2,3 & $\mathrm{I}, 5$ & $\mathrm{I}, 5$ \\
\hline 2009 & 9,4 & 6,I & 5,2 & 56 & 86 & 2,8 & $\mathrm{I}, 8$ & I, 6 \\
\hline 2010. & 9,6 & 4,7 & 4,4 & 45 & 93 & 2,9 & $\mathrm{I}, 4$ & $\mathrm{I}, 3$ \\
\hline 2 OII. & IO,3 & 9,4 & 7,9 & 76 & 84 & $3, \mathrm{I}$ & 2,8 & 2,4 \\
\hline $2 \mathrm{OI} 2$. & 5,6 & 4,9 & 3,7 & 66 & 76 & $\mathrm{I}, 7$ & $\mathrm{I}, 5$ & $\mathrm{I}, \mathrm{I}$ \\
\hline 2013. & 6,0 & 5.9 & 3,8 & 63 & 65 & $\mathrm{I}, 8$ & $\mathrm{I}, 8$ & $\mathrm{I}, 2$ \\
\hline Ukupno & 107,7 & 72,2 & 56,8 & & & & & \\
\hline
\end{tabular}

Izvor: Izrada autora temeljem podataka Ministarstva financija $\mathrm{RH}$

Tablica 2.

Odobrena jamstva po poduzećima od 200I. do 2013. (u mlrd. kuna)

\begin{tabular}{|c|c|c|c|c|c|c|c|c|c|c|c|c|c|c|}
\hline & 200I. & 2002. & 2003. & 2004. & 2005. & 2006. & 2007. & 2008 & 2009. & 2010. & 2011. & 2012. & 2013. & $\begin{array}{l}\text { Ukupno } \\
\text { 200I-I3. }\end{array}$ \\
\hline $\mathrm{HC}$ & 0,4 & 0,0 & 0,6 & 0,2 & 0,6 & $\mathrm{I}, 2$ & 0,5 & $\mathrm{I}, 2$ & 0,8 & $\mathrm{I}, 4$ & $\mathrm{I}, 2$ & $\mathrm{I}, 8$ & $\mathrm{I}, 5$ & $\mathrm{II}, 4$ \\
\hline HAC & $\mathrm{I}, 3$ & 3,0 & 2,7 & 2,2 & $\mathrm{I}, 9$ & $\mathrm{I}, 5$ & 2,6 & 3,I & 3,4 & 2,9 & 6,8 & $\mathrm{I}, 9$ & 2,0 & 35,3 \\
\hline ARZ & I,6 & 0,9 & 0,0 & $\mathrm{o}, \mathrm{O}$ & 0,0 & $\mathrm{I}, 9$ & 3,3 & $\mathrm{I}, \mathrm{O}$ & $\mathrm{I}, \mathrm{O}$ & $\mathrm{o}, \mathrm{O}$ & $\mathrm{O}, \mathrm{O}$ & 0,0 & 0,4 & IO,I \\
\hline Ukupno & 3,4 & 3,9 & 3,3 & 2,4 & 2,5 & 4,6 & 6,5 & 5,3 & 5,2 & 4,4 & 7,9 & 3,7 & 3,8 & 56,8 \\
\hline
\end{tabular}

Izvor: Izrada autora temeljem podataka Ministarstva financija RH

Država gotovo u cijelosti jamči obveze sva tri društva, tako da se analizom državnih jamstava može dobiti slika uvjeta zaduživanja, potencijalnih rizika dospijeća kredita i zajmova koje su javnim poduzećima odobravale domaće i inozemne poslovne banke te međunarodne financijske institucije (EIB, EBRD i IBRD).

\section{FINANCIJSKE OBVEZE I DRŽAVNA JAMSTVA ZA GESTE}

Temeljem podataka iz financijskih izvještaja, može se utvrditi da financijske obveze (uglavnom krediti) javnih trgovačkih društava cestovnog prometa rastu s 32,5 mlrd. 2009. na 38,9 mlrd. kuna 20I3. (s 9,8 na II,8\% BDP-a). Najveći rast bilježe financijske obveze HC-a za oko 4 mlrd. kuna, te za 2,6 mlrd. kuna obveze HAC-a. Financijske obveze ARZ-a postupno se smanjuju. 
Tablica 3.

Ukupne financijske obveze trgovačkih društava od 2009. do 20I3. (u mlrd. kuna i \% BDP-a)

\begin{tabular}{|c|c|c|c|c|c|}
\hline & 2009. & 2010. & 2011. & 2012. & 2013 \\
\hline Autocesta Rijeka-Zagreb & 7,7 & 7,7 & 7,6 & 7,3 & 7,3 \\
\hline Hrvatske autoceste & 19,9 & $2 \mathrm{I}, \mathrm{O}$ & $2 \mathrm{I}, 5$ & 22,5 & 22,7 \\
\hline Hrvatske ceste & 4,8 & 5,9 & 6,8 & 7,8 & 8,8 \\
\hline Ukupno & 32,5 & 34,5 & 36,0 & 37,5 & 38,9 \\
\hline$\%$ BDP-a & 9,8 & IO,5 & IO,8 & $\mathrm{II}, 3$ & II,8 \\
\hline
\end{tabular}

Izvor: Financijski izvještaji društava od 2009. do 2013.

Ukupne kreditne obveze HC-a na kraju 20I3. su 8,8 mlrd. kuna. Dugoročne obveze su oko 8 mlrd., a država je jamčila za 7 mlrd. kuna obveza (zajmovi i krediti EIB, IBRD, EBRD). Za HC su najkritičnije naredne četiri godine, kad na naplatu dolazi gotovo polovica kreditnih obveza - 4,5 mlrd. kuna (v. tabl. 3.I. u prilogu).

U narednih pet godina, HAC-u na naplatu dolazi gotovo I8 mlrd. kuna kreditnih obveza, a samo tijekom 20I4. gotovo 5 mlrd. (v. tabl. 3.2. u prilogu).

U 20I3. ARZ je od 8,8 mlrd. kuna kredita otplatio tek I,5 mlrd., a društvu ostaje dug po glavnici kredita $u$ iznosu od 7,3 mlrd. kuna. Poduzeće je kratkoročno nelikvidno, dugoročne obveze veće su od ukupne imovine za 56\%. Stavka kapitala je u minusu, jer ARZ ostvaruje gubitak iznad visine kapitala. ARZ-u tijekom 20I4. na naplatu dolazi oko I mlrd. kuna kredita, a u narednih 5 godina još 2 mlrd. kuna (v. tabl. 3.3. u prilogu).

Treba istaknuti da je najveći dio obveza cestovnih poduzeća dugoročan (više od 80\%), s određenim varijacijama koje su uglavnom vezane uz nova zaduživanja kratkih rokova. HAC ima relativno nepovoljniju strukturu dospijeća obveza u kojima kratkoročne obveze sudjeluju s više od $20 \%$. Ukupne kratkoročne obveze svih poduzeća rasle su s 3,7 mlrd. kuna u 2009. na 7,76 mlrd. kuna u 2013.

Tablica 4.

Udio dugoročnih u ukupnim financijskim obvezama od 2009. do 2013. (u \%)

\begin{tabular}{|c|c|c|c|c|c|}
\hline & 2009. & 2010. & 2011. & 2012. & 2013 \\
\hline Autocesta Rijeka-Zagreb & 98 & 97 & 95 & 94 & 80 \\
\hline Hrvatske autoceste & 83 & 72 & 89 & 88 & 76 \\
\hline Hrvatske ceste & 95 & 92 & 84 & 90 & 90 \\
\hline Ukupno & 89 & $8 \mathrm{I}$ & 89 & 90 & 80 \\
\hline
\end{tabular}

Izvor: Izrada autora temeljem podataka iz financijskih izvještaji društava od 2009. do 2013.

Rast udjela kratkoročnih obveza stvara dodatni pritisak na likvidnost i solventnost poduzeća, a rezultat je primarno slabog financijskog poslovanja (visokih obveza i nepovoljne strukture troškova), zbog čega vjerovnici nisu skloni odobravati dugoročne kredite.

\section{STRUKTURA OBVEZA I JAMSTAVA}

Zahvaljujući analizi državnih jamstava, neizravno je moguće dobiti uvid u strukturu financijskih obveza javnih poduzeća iz cestovnog prometa. Većina je tih informacija raspršena po financijskim izvještajima, godišnjim izvještajima Ministarstva financija, „Narodnim novinama” (dio međunarodnih ugovora) itd. Nažalost, nema sistematiziranog pregleda na jednome mjestu.

Uvjeti zaduživanja. Od 2012. do 20I4., cestovna trgovačka društva zadužuju se uglavnom za programe građenja, održavanje cesta i autocesta te podmirivanje kreditnih obveza. Zadužuju se za razdoblje do 7

4 NEWSLETTER 92 | A. BAJO i J. PETRUŠIĆl Državna jamstva i financijske obveze javnih trgovačkih... I Institut za javne financije 
godina, s fiksnim kamatnim stopama (od 4 do 5,6\%), uvećanim za varijabilni dio obično šestomjesečni ili tromjesečni (6M ili 3M) Euribor. Troškovima kamata treba dodati i visoke bankovne naknade koje se obično zaračunavaju jednokratno - u postotku iznosa kredita. Od 20I2. do 20I4. troškovi jednokratne naknade za I5 odobrenih kredita iznose oko I8,9 mil. eura, odnosno I44,6 mil. kuna. Tu su još i dodatni troškovi agentske naknade banaka koji se kreću od 2-20 tisuća eura godišnje (ukupno oko 44I tisuća eura, odnosno 3,36 mil. kuna). Zbog dodatnih bankovnih naknada, efektivne kamatne stope kreću se u rasponu od 6-7\%.

Valutna struktura. Od 57 mlrd. kuna odobrenih jamstava, čak 53 mlrd. je u eurima (više od 90\%). Tako su čak sva jamstva (i kreditne obveze) ARZ-a u eurima. Krediti u kunama malo su zastupljeni - tek 6,33\% kod HC-a i I,I6\% kod HAC-a. Kreditne obveze denominirane u dolarima sudjeluju sa 7,9\% i prisutne su jedino kod HAC-a. To znači da su kreditne obveze društava izložene valutnom riziku, a u slučaju deprecijacije kune značajno bi se pogoršao teret otplate duga (v. graf. I.)

Vjerovnici. Od 200I. do 2006. glavni su vjerovnici međunarodne financijske institucije, a rijetko domaće poslovne banke. Od 2006. do 20I4. prisutnije su domaće i inozemne poslovne banke - međunarodnih financijskih institucija gotovo da i nema, izuzev 20Io. i 20II. (v. graf. 2.). Kod sva tri društva, vjerovnici su domaće i inozemne poslovne banke i međunarodne financijske institucije. Domaće poslovne banke kreditiraju ih s oko 20 mlrd. kuna, a inozemne s oko I9 mlrd. (od čega se I3 mlrd. odnosi na HAC). Zanimljivo, inozemne poslovne banke nisu kreditirale HC. Međunarodne financijske institucije podjednako su odobravale zajmove i kredite za sva tri poduzeća (ukupno 2 mlrd. kuna). Otvoreno je pitanje zašto se država za infrastrukturne projekte $u$ većoj mjeri ne zadužuje kod međunarodnih financijskih institucija, nego se (ne)svjesno izlaže visokim financijskim rizicima zaduženja kod inozemnih i domaćih poslovnih banaka (čak i kod Poštanske banke) kojima je - uz visoke kamatne stope - izrazito poželjan klijent.

Ročnost obveza. Sudeći po analizi jamstava po ročnosti, može se zaključiti da je najveći dio jamstava za kredite i zajmove (29\%) za cestovna poduzeća odobren na rok od 5 do Io godina u iznosu od I6,4 mlrd. kuna. Najmanje je odobreno na kratki rok - do 5 godina ( $8 \%$ ili 4,6 mlrd. kuna), te onih preko 20 godina (II\% ili 6,3 mlrd. kuna). Od 200I. do 20I3. poduzećima cestovnog prometa izdano je 80 jamstva $\mathrm{s}$ prosječnim dospijećem od 12 godina. Od 200I. do 2007. prosječno dospijeće je oko I6 godina, no u posljednje dvije godine prosječni rokovi dospijeća se skraćuju na oko 7 godina (v. tabl. 5. i 6. u prilogu). Visoke potrebe za zaduživanjem cestovnih trgovačkih društava uz visoke financijske rizike zbog rasta javnog duga, pridonijeli su rastu kamatnih stopa, smanjenju rokova dospijeća čak i za zaduženje uz državna jamstva. Očito je kredibilitet države i javnih cestovnih društava značajno narušen, pa državna jamstva gotovo i nemaju utjecaja na uvjete zaduživanja (rokove i visinu kamatnih stopa). Rast kratkoročnih obveza cestovnih poduzeća znak je povećanja financijskih rizika oko otplata duga koji će naročito biti prisutni u iduće četiri godine.

Potencijalna dospijeća. Poduzeća su stvorila obveze za otplatu glavnice i kamata (za koje im jamči država) do 2034. Najveći dio obveza dospijeva 2017., 2018. i 2019. kada bi - u samo tri godine - državi trebalo doći na naplatu I7,2 mlrd. kuna (v. graf. 3.).

\section{OBVEZE GESTOVNIH TRGOVAČKIH DRUŠTAVA, MONETIZAGIJE I FINANCIJSKI RIZIGI}

Obveze cestovnih trgovačkih društava su velike, a HAC i ARZ ih nisu u mogućnosti financirati bez potpora iz državnog proračuna. Financijski rizici cestovnih poduzeća su visoki zbog visoke zaduženosti. Cestovna poduzeća (naročito ARZ) su dodatno izložena kamatnom, kreditnom i riziku likvidnosti. Većina je kredita u eurima, zbog čega postoje troškovi negativnih tečajnih razlika ${ }^{3}$. Kamatne stope su promjenjive, što cestovna društva dodatno izlaže rizicima promjena kamata.

${ }^{3}$ ARZ je 20I3. imao 88,3 mil. kuna troškova zbog negativnih tečajnih razlika. 
Vlada je 20I2. odlučila tražiti izvanproračunski model financiranja, kako bi smanjila teret obveza koje dospijevaju do 2OI8. Angažirala je zajednicu društava (Erste Group Bank AF, Deloitte savjetodavne usluge d.o.o., Wolf Theiss Rechtsanwalte $\mathrm{GmbH}$ - podružnica Zagreb, te društva za upravljanje autocestama Asfinag International) kao savjetnike za mogući model monetizacije autocesta (koncesija, obveznice osigurane prihodom od cestarine, ugovor o upravljanju, privatizacija autocesta i privatizacija operatora autocesta). Savjetnici su odabir suzili na dva modela monetizacije: dodjela koncesija za upravljanje i održavanja autoceste i izdavanje projektnih obveznica (koje bi se otplaćivale prihodima od cestarine). Nakon obavljenih analiza, najbolji se pokazao model koncesije. Autoceste bi se dale u koncesiju na 30-40 godina, uz koncesijsku naknada u rasponu od 2,4 do 2,9 mlrd. eura. Ukoliko bi se koncesijsko razdoblje produljilo na 50 godina, procijenjeni bi iznos naknade mogao rasti na 3,4 mlrd. eura. Takva bi koncesija bila najveće inozemno ulaganje u povijesti RH. Taj projekt slijedio je Vladin Program restrukturiranja HAC-a za razdoblje 20I2.-I5., kojim je, i prije monetizacije, predviđeno restrukturiranje društva s ciljem smanjenja troškova upravljanja i održavanja autocesta te visoke kreditne zaduženosti. U tom je modelu osnovano poduzeće posebne namjene (HAC ONC). Nakon proteka koncesijskog vremena, ekonomska vrijednost javnog dobra se vraća državi.

Vlada je do 20I4. trebala obaviti restrukturiranje društava, te do listopada 20I4. obaviti cijeli proces odabira, zaključenja ugovora, a od investitora (koncesionara) dobiti iznos naknade za koncesiju. Za sada je izvjesno da taj proces 20I4. neće završiti.

Svi nedostaci i rizici koji su postojali, a nisu riješeni procesom restrukturiranja društava, mogli bi utjecati na potencijalne iznose naknada za koncesije.

Potencijalni rizik jeste činjenica da se davanje autocesta u koncesiju obavlja u uvjetima kada ne postoji dobar uvid u uvjete njihovih prethodnih zaduživanja, bez detaljne razrade otplata kamate i glavnice duga do 2034., uz brojne financijske i ostale rizike poslovanja. Mimo tih problema, postoji i niz dodatnih rizika vezanih primarno uz vrednovanje i procjene vrijednosti imovine cestovnih poduzeća, financijskih rizika zbog sudskih sporova, neizvjesnih dodatnih zahtjeva sindikata itd.

HAC ima oko 6I3 mil. kuna sudskih tražbina (u 20I3.) zbog sudskih sporova. Te tražbine mogu itekako utjecati na poslovanje društva, ukoliko ne postoji procjena očekivanih ishoda sudskih sporova kao ni procjena njihova očekivanog trajanja. Zbog toga je teško utvrditi opravdanost visine obavljenih rezervacija zbog potencijalno mogućih odljeva sredstava.

ARZ je značajno izložen financijskim rizicima. Za HC (koji nije u fokusu monetizacije) i dalje ostaju ozbiljni problemi vrednovanja i utvrđivanja stvarne vrijednosti imovine. Od 2000. HC nije proveo procjenu vrijednosti cesta i objekata, zbog čega su neovisni revizori 20I2. i 20I3. dali uvjetovano mišljenje na financijske izvještaje. Problem je što HC nema u cijelosti raščišćene imovinsko-pravne odnose vlasništvo nad nekretninama (proces u tijeku), a nema ni razrađenu metodologiju procjene vrijednosti javnih cesta (u procesu je izrada metodologije) i obavljanja procjena. Osim toga, protiv poduzeća se vodi značajan broj sudskih sporova (oko 328 mil. kuna sudskih tražbina u 20I3.).

Čak i potencijalni rizici (slabosti u vrednovanju imovine, parnični postupci itd.) nisu zapreka zainteresiranim investitorima za ulaganje $u$ autoceste. Međutim, takvi nedostaci mogu utjecati na konačni iznos koncesijske naknade. Za Vladu je jako bitno da detaljno specificira uvjete odobravanja koncesije, a naročito da riješi sve dileme i rizike koji mogu utjecati na iznos koncesije. Takav posao traži i zahtijeva značajan profesionalni i stručni angažman.

S obzirom da monetizacija može utjecati na visinu duga i proračunskog deficita, za njenu će provedbu trebati i potvrda Europske komisije, jer se Hrvatska nalazi u proceduri prekomjernog proračunskog deficita. 


\section{ZAKLJUČAK}

Javna poduzeća iz cestovnog prometa u posljednje se dvije godine zadužuju uz relativno nepovoljne uvjete kod domaćih i inozemnih poslovnih banaka, i to na rokove kraće od 7 godina. Dugovi cestovnih poduzeća od 20I4. u cijelosti su evidentirani kao dug opće države, čime se kao imperativ za državu postavlja izrada i donošenje Strategije upravljanja javnim dugom. U sklopu te Strategije Vlada naročito treba voditi računa o rizicima dospijeća obveza cestovnih poduzeća i iznalaženju najboljih instrumenata za refinanciranje njihovih obveza.

Zbog iznimno slabe financijske pozicije HAC-a i ARZ-a, uzrokovane intenzivnim zaduživanjem prethodnih godina, gotovo je sigurno da ta poduzeća ne mogu vraćati kamate i glavnicu bez novog zaduživanja. U cilju smanjenja mogućnosti nastanka kreditnih rizika, Vlada mora nastaviti s restrukturiranjem cestovnih poduzeća. Model monetizacije (davanja u koncesiju) hrvatskih autocesta u tom procesu može biti koristan.

Na Vladi je zadatak da cjelovito pristupi rješavanju problema cestovnih poduzeća koja zbog visokih obveza stvaraju stalni pritisak na državu za daljnja zaduženja i povećanja duga opće države. Ukoliko obavi monetizaciju autocesta, Vlada dobiva na raspolaganju 3-5 godina za stabilizaciju javnog duga i obavljanje snažnih rezova u restrukturiranju javnih društava - smanjenja troškova zaposlenih, subvencija $\mathrm{i}$ zaduživanja. I uz obavljenu monetizaciju, državi ostaje obveza otplate glavnica i kamata duga cestovnih poduzeća. Međutim, monetizacijom (davanjem u koncesiju) autocesta, država dobiva jednokratni prihod od naknade za koncesiju, kojim može podmiriti dio obveza koje dospijevaju na naplatu u idućih 3-5 godina. Ukoliko se država neće poslužiti modelom monetizacije autocesta, morat će se u njihovu upravljanju ponašati i poslovati na isti način kao što bi to radio privatni koncesionar.

\section{LITERATURA}

ARZ, 20I3. Godišnje izvješće o poslovanju Autoceste Rijeka-Zagreb d.d. u 20I3. Zagreb: Autocesta RijekaZagreb.

Bajo, A. i Primorac M., 20I4. Promjene metodološkog obuhvata javnog duga i proračunskog deficita. Aktualni osvrt, br. 70.

Bajo, A., Primorac, M. i Andabaka, A., 20II. Osnove upravljanja javnim dugom. Zagreb Institut za javne financije.

HAC, 20I2. Sažetak programa restrukturiranja za razdoblje 20I2.-I5. Zagreb: Hrvatske autoceste.

HAC, 20I3. Godišnji financijski izvještaji i Izvješće neovisnog revizora za 2013. godinu. Zagreb: Hrvatske autoceste.

MPPI, 20I3. Monetizacija javnog duga vezano za društva HAC i ARZ - Nacrt konačnog izvješća u Fazi I (radi pregleda $\mathrm{i}$ komentara MPPI). Zagreb: Ministarstvo pomorstva, prometa i infrastrukture.

Petrušić, J., 20I4. Državna jamstva trgovačkim društvima iz sektora cestovnog prometa. Diplomski rad. Zagreb: Ekonomski fakultet.

Zakon o cestama, NN 84/II, 22/I3, 54/I3, I48/I3, 92/I4. Zagreb: Narodne novine. 


\section{PrILOG}

Tablica 3.I.

Pregled kreditnih obveza prema bankama u zemlji i inozemstvu HC-a, stanje 31.I2.2013. (u mlrd. kuna) Dospijeće stanje Kratkoročni dio

Dugoročni dio

\begin{tabular}{|c|c|c|c|c|}
\hline \multicolumn{5}{|l|}{ Domaće banke } \\
\hline Privredna banka Zagreb d.d. & $2 \mathrm{OI} 5$ & $\mathrm{O}, \mathrm{O} 4$ & $\mathrm{O}, \mathrm{O} 3$ & $\mathrm{O}, \mathrm{OI}$ \\
\hline Zagrebačka banka & $2 \mathrm{OI} 5$ & $\mathrm{O}, \mathrm{O} 4$ & $\mathrm{O}, \mathrm{O} 2$ & $\mathrm{O}, \mathrm{OI}$ \\
\hline PBZ d.d. i ZABA d.d. & 2025. & 0,37 & $\mathrm{O}, \mathrm{O} 3$ & 0,34 \\
\hline ZABA d.d., PBZ d.d. i SG - Splitska banka d.d. & 2019. & 0,30 & 0,05 & 0,25 \\
\hline ZABA d.d. & $2 \mathrm{O} 23$. & 0,54 & O,06 & 0,48 \\
\hline PBZ d.d. i ZABA d.d. & 2023. & 0,50 & O,O5 & 0,45 \\
\hline Banca Infrastrutture Innovazione e Sviluppo SpA & 2017. & 0,67 & $\mathrm{O}, \mathrm{I7}$ & 0,50 \\
\hline Klupski dugoročni kredit I & 2022. & $\mathrm{I}, \mathrm{I} 8$ & & $\mathrm{I}, \mathrm{I} 8$ \\
\hline Klupski dugoročni kredit II & 2019. & 0,84 & $\mathrm{O}, \mathrm{I5}$ & 0,69 \\
\hline Klupski dugoročni kredit III & 2019. & $\mathrm{I}, \mathrm{O} 2$ & O,o9 & 0,93 \\
\hline PBZ d.d. i SG - Splitska banka d.d. & $2 \mathrm{O} 2 \mathrm{I}$. & 0,40 & & 0,40 \\
\hline Erste \& Steiermärkische Bank & 2023. & 0,50 & & 0,50 \\
\hline BKS Banka d.d., Croatia banka d.d. & $2 \mathrm{O} 2 \mathrm{O}$. & 0,57 & & 0,57 \\
\hline Ukupne obveze prema bankama u zemlji & & 6,98 & 0,65 & 6,33 \\
\hline \multicolumn{5}{|l|}{ Inozemne banke } \\
\hline Europska investicijska banka I & 2027. & 0,38 & $\mathrm{O}, \mathrm{O} 3$ & 0,36 \\
\hline Međunarodna banka za obnovu i razvoj & 2018. & 0,26 & O,06 & 0,20 \\
\hline $\begin{array}{l}\text { Europska investicijska banka II } \\
\text { (projekt Obnove državnih cesta - betterment II) }\end{array}$ & 2030. & 0,45 & $\mathrm{O}, \mathrm{O} 2$ & 0,43 \\
\hline Europska investicijska banka III (Splitska obilaznica) & 2036. & $\mathrm{O}, \mathrm{I} 4$ & 0,00 & $\mathrm{O}, \mathrm{I} 3$ \\
\hline Europska banka za obnovu i razvoj & $2 \mathrm{O} 3 \mathrm{I}$. & 0,22 & $\mathrm{O}, \mathrm{OI}$ & 0,20 \\
\hline Europska investicijska banka IV & 2034. & O,3I & & $0,3 \mathrm{I}$ \\
\hline Ukupne obveze prema bankama u inozemstvu & & $\mathbf{I}, 75$ & $\mathbf{0 , 1 2}$ & $\mathbf{1 , 6 3}$ \\
\hline Ukupno & & 8,73 & 0,77 & 7,96 \\
\hline
\end{tabular}

Izvor: Izrada autora temeljem podataka HAC (2013)

Tablica 3.2.

Pregled dospijeća dugoročnih kreditnih obveza HC-a i HAC-a (u mlrd. kuna)

\begin{tabular}{|c|c|c|c|c|c|c|c|}
\hline & 2014. & 2015. & 2016. & 2017. & 2018. & $\begin{array}{c}\text { Nakon } \\
2018 .\end{array}$ & Ukupno \\
\hline Hrvatske ceste & 0,7 & $\mathrm{I}, \mathrm{O}$ & $\mathrm{I}, 2$ & $\mathrm{I}, 2$ & $\mathrm{I}, \mathrm{O}$ & 3,5 & 8,7 \\
\hline Hrvatske autoceste & 4,9 & 2,9 & 2,4 & 3,9 & 3,8 & 4,3 & 22,3 \\
\hline
\end{tabular}

Izvor: Izrada autora temeljem podataka Godišnjeg financijskog izvješća i izvješća neovisnog revizora za 2013. 
Tablica 3.3.

Pregled kredita za financiranje izgradnje autoceste Rijeka-Zagreb s državnim jamstvom na dan 31. 12. 2013.

\begin{tabular}{|c|c|c|c|}
\hline Kredit & Povučeno & Otplaćeno & Dug po glavnici \\
\hline EIB & 0,06 & $\mathrm{O}, \mathrm{O} 2$ & $\mathrm{O}, \mathrm{O} 4$ \\
\hline EBRD & 0,06 & 0,04 & 0,02 \\
\hline EIB & $0,2 \mathrm{I}$ & O,OI & 0,20 \\
\hline EBRD & 0,05 & O,OI & $\mathrm{O}, \mathrm{O} 4$ \\
\hline KFW & $\mathrm{O}, \mathrm{I3}$ & 0,04 & O,IO \\
\hline KFW & O,II & $\mathrm{O}, \mathrm{OI}$ & $\mathrm{O}, \mathrm{IO}$ \\
\hline DEXIA GREDIT LOKAL & 0,20 & 0,05 & O,I5 \\
\hline $\begin{array}{l}\text { KOMMUNALKREDIT AUTRIJA AG, INTESA } \\
\text { SANPAOLO }\end{array}$ & $\mathrm{O}, \mathrm{I} 4$ & $\mathrm{O}, \mathrm{O} 3$ & O,II \\
\hline JP Morgan & $\mathrm{O}, \mathrm{I} 4$ & & $\mathrm{O}, \mathrm{I} 4$ \\
\hline ZABA, HAAB, OTP & o,o6 & & 0,06 \\
\hline Ukupno & $\mathrm{I}, \mathrm{I} 5$ & O,I9 & 0,96 \\
\hline
\end{tabular}

Izvor: ARZ (2013:5I)

Tablica 5.

Ročnost izdanih jamstava sektoru cestovnog prometa, 200I-20I4. (u mlrd. kuna)

\begin{tabular}{ccc} 
Godine & Iznos (u mlrd. kuna) \\
\hline do 5 & 4,6 \\
\hline 5 do IO & I6,4 \\
\hline IO do I5 & I4,6 \\
\hline I5 do 20 & I4,9 \\
\hline više od 20 & 6,3 \\
\hline Ukupno & 56,8 \\
\hline
\end{tabular}

Izvor: Izrada autora temeljem podataka Ministarstva financija $\mathrm{RH}$

Tablica 6.

Prosječno dospijeće jamstava odobrenih poduzećima iz cestovnog prometa po godinama

\begin{tabular}{|c|c|c|c|c|}
\hline Godina izdanja & $\begin{array}{c}\text { Prosječne godine } \\
\text { dospijeća }\end{array}$ & HC & HAC & ARZ \\
\hline $200 I$. & $\mathrm{II}, 4$ & 25,0 & IO,O & 9,0 \\
\hline 2002. & $\mathrm{I} 4,8$ & - & II,7 & I9,5 \\
\hline 2003. & $\mathrm{I} 4,4$ & 15,0 & $\mathrm{I} 4,3$ & - \\
\hline 2004. & $\mathrm{I} 8, \mathrm{O}$ & II,O & 20,3 & - \\
\hline 2005 & 15,0 & $\mathrm{I} 5,5$ & $\mathrm{I} 4,5$ & - \\
\hline 2006. & 19,9 & $2 \mathrm{I}, 3$ & I5,O & 25,0 \\
\hline 2007. & I5,6 & $\mathrm{I} 2, \mathrm{O}$ & 13,3 & I9,O \\
\hline 2008. & $\mathrm{II}, \mathrm{O}$ & I5,O & 8,3 & $\mathrm{I} 4, \mathrm{O}$ \\
\hline 2009 & 3,3 & 2,0 & 3,5 & 5,0 \\
\hline 2010. & 7,3 & IO,O & IO,5 & - \\
\hline 2 OII. & $\mathrm{I} 2, \mathrm{I}$ & II,O & $\mathrm{I} 2,3$ & - \\
\hline 2012. & 6,5 & 7,0 & 6,0 & - \\
\hline 2013. & 6,8 & 8,3 & 5,0 & 6,0 \\
\hline Prosjek razdoblja & $\mathrm{I} 2, \mathrm{O}$ & $\mathrm{I} 2,8$ & II,I & $\mathrm{I} 3,9$ \\
\hline
\end{tabular}

Izvor: Izrada autora temeljem podataka Ministarstva financija RH 


\section{Grafikon I.}

Valutna struktura izdanih državnih jamstava 200I. do 20I4. (u \%)

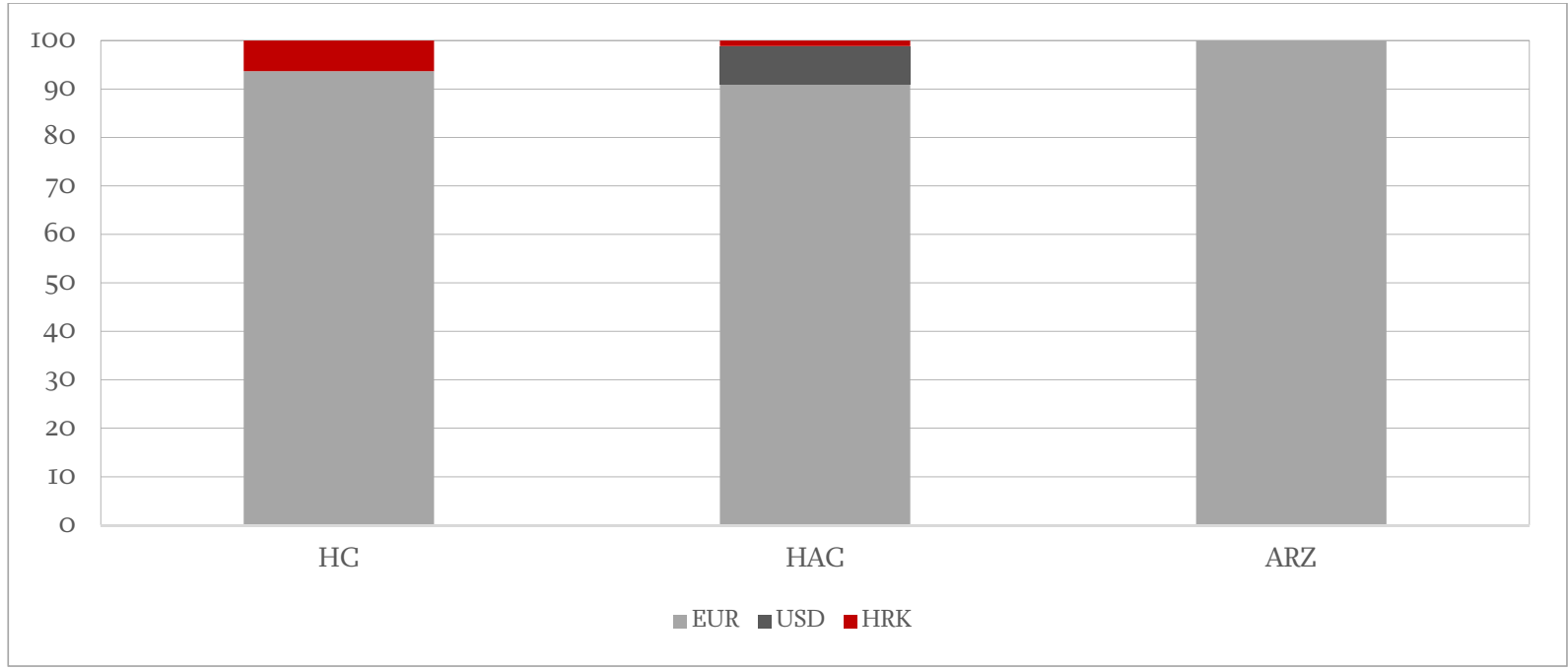

Izvor: Izrada autora temeljem podataka Ministarstva financija $\mathrm{RH}$

\section{Grafikon 2.}

Struktura izdanih jamstava sektoru cestovnog prometa prema vrsti vjerovnika (u mlrd. kuna)

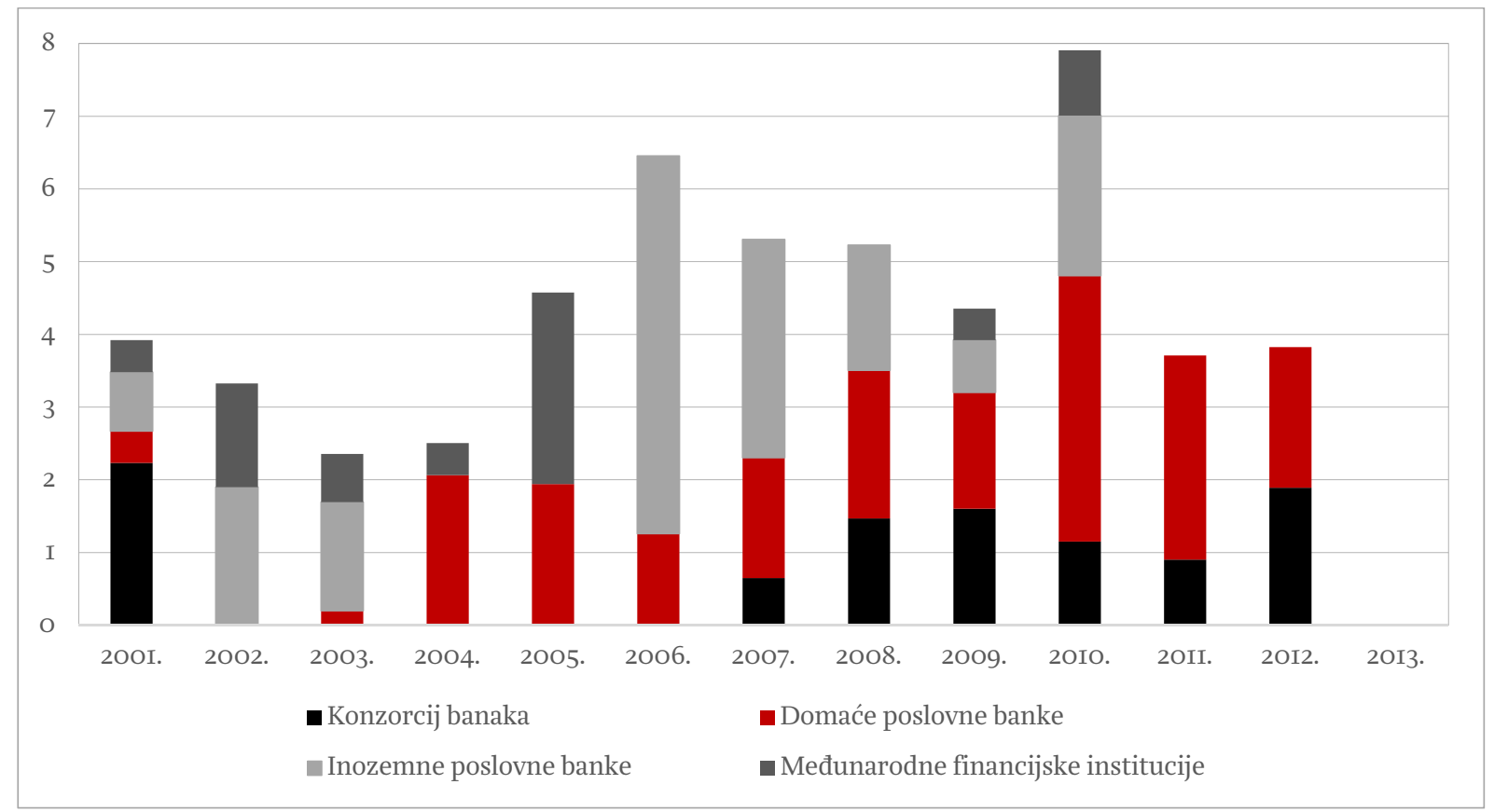

Izvor: Izrada autora temeljem podataka Ministarstva financija $\mathrm{RH}$ 


\section{Grafikon 3.}

Potencijalna dospijeća jamstava odobrenih sektoru cestovnog prometa, 2004. do 2034. (u mlrd. kuna)

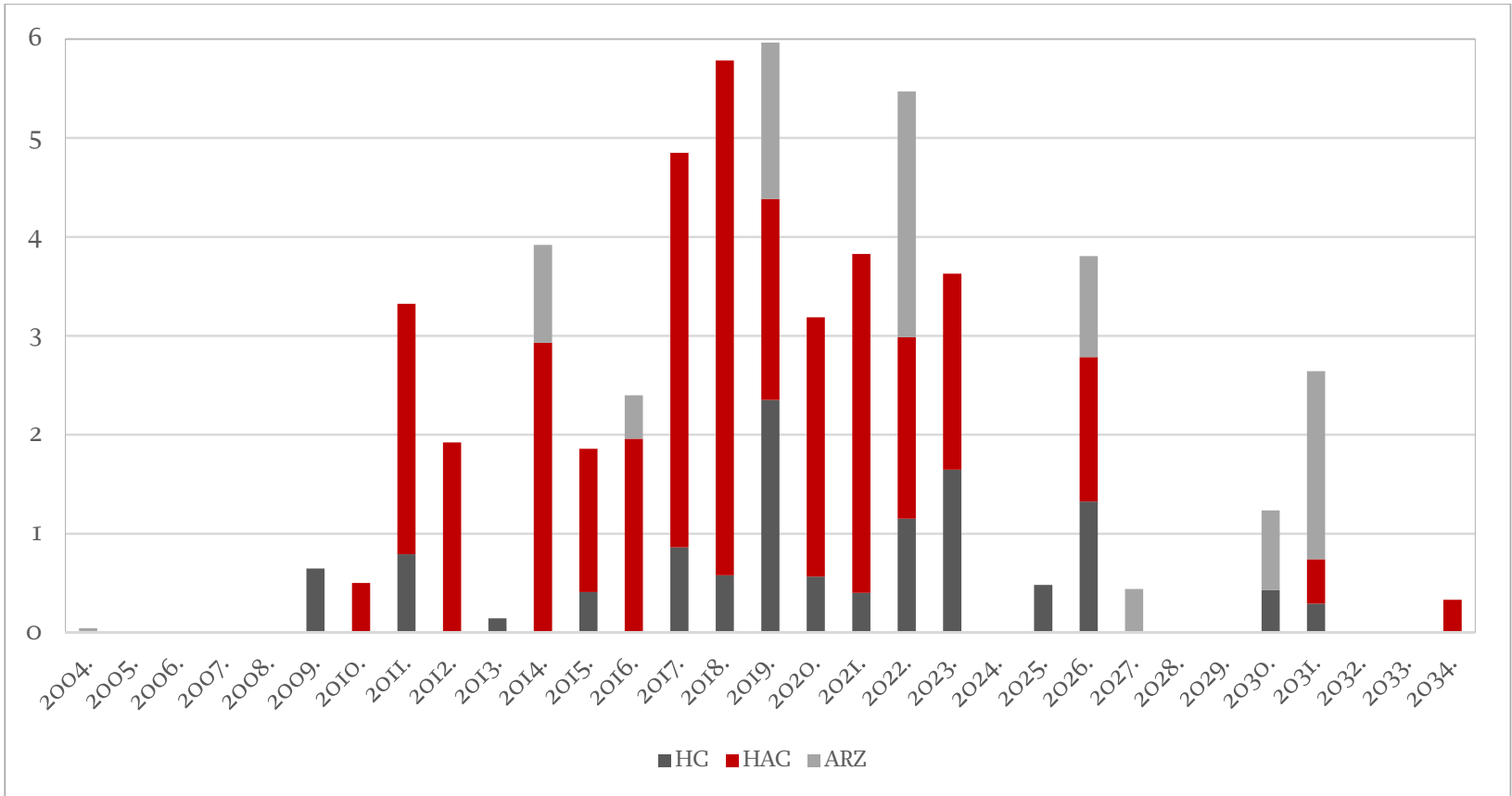

Izvor: Izrada autora temeljem podataka Ministarstva financija $\mathrm{RH}$ 